\title{
Pensions and hotels at the tourist and sports trails of the Giant Mountains
}

\author{
Anna Wojtas-Harań \\ https://orcid.org/0000-0002-8434-7348 \\ anna.wojtas-haran@pwr.wroc.pl \\ Department of Housing, Industrial Architecture, Interiors, Rural Planning, Landscape \\ and Visual Arts K6, Faculty of Architecture, Wroclaw University of Technology
}

\begin{abstract}
A characteristic feature of the first guesthouses and hotels in the towns located in the Giant Mountains was their location in close connection with nature. Usually, the developments from the turn of the $20^{\text {th }}$ century freely blended in with a green space amongst immeasurable mountain landscape or a romantic park layout as well as sports and recreation areas. Sports venues such as toboggan runs, bobsleigh runs, ski jumping hills, ski lifts, ski runs, tennis courts, swimming pools and ice rinks were situated in a way giving the impression of a compositional and functional whole with villas and guesthouses. They were placed within larger green spaces with a wide view of the Giant Mountains range from one side or the Jizera Mountains on the other, in direct contact with forest nature and fresh air. The tourist and residential developments were supposed to be an elegant background for sporting events with the mutual use of all natural values of the landscape. Over time, a change in the needs and expectations of tourists and athletes resulted in the fact that some sports areas lost their original purpose or were re-developed. In this situation, guesthouses and hotels lost their attractive neighbourhood. Apart from many other reasons, the harmony between developed areas and open, green areas was disturbed.
\end{abstract}

Keywords: sports venues, guesthouses, hotels, green areas, sports stations

\section{Introduction}

Attractiveness of holiday and resort towns depends largely on values of the natural environment. The mountain landscape as well as natural or arranged by a designer's hand greenery, add charm to summer, winter resorts, and spas. This reference to obvious truths seems purposeful in the discourse about recreational areas in the Giant Mountains. In some places the Giant Mountains are still wild, quiet, threatening, and beautiful. They can be admired or experienced in a more tangible way. They are also an area where it is possible to 'get away from the world' and 'switch to nature'. How long will they remain 'in harmony with nature'?

A strong relationship between tourism, recreation and the natural environment has been evident since the beginning of the development of these activities. It was reflected in the way of erecting guesthouses, hotels, villas, hostels and in land development. These structures were built in the most beautiful places of the landscape with a possibility of direct benefiting from advantages of the natural environment.

Relations were gradually changing. Tourism was separated from unpredictable natural conditions. Mountains are treated subjectively and equally with sports equipment. Natural values of many places have become secondary. Resorts, which were once comfortable and safe enclaves for experiencing the natural environment, have become centres with infrastructure and development methods identical to those of the city. At present, seasonality is a feature that distinguishes them from other forms of urbanization [Diener 2005]. Several times a year, resorts rife with guests in order to become frozen in other months offering deserted blocks of flats.

The Giant Mountains resorts have their own history in a trend of the global change. They flourished at the end of the $19^{\text {th }}$ century and in the $1^{\text {st }}$ half of the $20^{\text {th }}$ century, in the period after the Second World War in the 1960 s, 1970s and 1980s. Nowadays, their values are being rediscovered. Post-war and the late 1980s poverty 
limited the expansion of developments in the Giant Mountains. A wave of experiments connected with the search for the most appropriate solutions to tourist resorts did not omit the Sudetes. Concepts for recreational development were created. However, many plans have not been implemented to this day and many concepts have been abandoned.

At present, spontaneously developing tourism and recreation is based to a large extent on a somehow decapitalized old infrastructure or modernized and rebuilt. New investments make the most of the acquired area. A sometimes saved 'patch of greenery' occasionally manifests local features of nature. This trend is changing the face of resorts.

\section{Objectives of the research}

The purpose of our study is:

- selection of development features which make up the quality and attractiveness of the Giant Mountains resorts;

- seeking solutions which will save the landscape, despite the pressure to meet the leisure industry requirements.

\section{Method}

The method of observation and case study was adopted.

Examples of properties from the most popular tourist resorts and at the same time ski resorts were selected, i.e. Szklarska Poręba and Karpacz.

The resorts of Szklarska Poręba and Karpacz were known for their healthy high-mountain climate and greenery, which was connected with natural conditions of the terrain.

Szklarska Poręba (Schreiberhau) was defined as a climatic alpine spa and winter sports station. It was a diversified extensive town concentrated in the valley of the River Kamienna.

The upper part of Karpacz (Brückenberg-Wang) was valued for its perfect, spa, and sports climate [Reichs 1938], thanks to its forests and location.

However, tourism development brings about the landscape transformation and air pollution. At present, more and more compact large-scale developments are beginning to take control not only of the centres but also enter the areas of forests, meadows, mountain peaks of the Jizera Mountains and the Giant Mountains.

Unusual locations were recalled, where in the scenery of the highest range of the Sudetes, surrounded by stylish architecture, supporters of winter and summer sports activities introduced a welcome revival. The choice was determined by the need to emphasize values of architecture which had always been the context of sporting events but is currently dying under the flood of developing resorts and is rebuilt as well as distorted also as a result of changing customs.

The form, architectural detail and land development were analyzed to obtain empirical conclusions.

\section{State of the research}

Architecture and spatial development of the Sudeten region were discussed in a variety of approaches, in particular when analysing the set of features shaping the regional development [Biesiekierski 1999, Suchodolski 1996, Trocka-Leszczyńska 1995] as part of research on the type of developments connected with tourist and spa services [Suchodolski 2005, Balińska 1991].

An important pretext for developing the document [Szymanski-Störtkuhl 1999] from 1999, which presented the history of the Giant Mountains culture, was the cooperation between the District Museum in Jelenia Góra and the Association of Interregional Cultural Exchange in Berlin and the Kreuzberg Museum in Berlin. It included a brief description of houses which belonged to artists, writers, scientists and intellectuals residing in Szklarska Poręba. The dissertation was based on German literature, i.e. descriptions of Alfred Koeppen's 
houses and landscapes from the beginning of the $20^{\text {th }}$ century as well as dissertations by artists and experts of culture. According to the assessment of Jerzy Ilkosz and Beate Szymanski-Störtkuhl, '... architectural traces, primarily houses owned by artists [who lived and worked in the Giant Mountains] did not arouse any interest so far' [Szymanski-Störtkuhl 1999, p. 104].

The history of the region is dealt with by archivist of Jelenia Góra Ivo Łaborewicz and historian Przemysław Wiater [taborewicz 2010], who in 2010 prepared a publication devoted to the history of Szklarska Poręba. It presents, among other things, archival photos of selected buildings and sports venues.

Krzysztof R. Mazurski [Mazurski 2012], Tomasz Przerwa [Przerwa 2012], Jacek Potocki [Potocki 2004, Potocki 2009], Julian Janczak [Janczak 1988, Janczak1976-1985], Tadeusz Steć and Wojciech Walczak [Steć 1962] et al. also dealt with the subject of sport, tourism and architecture in the Sudetes.

The topic of sports complexes greenery from the interwar period in Lower Silesia was taken up by Sebastian Wróblewski [Wróblewski, 2016], who discussed sports venues connected in particular with summer recreation.

Regarding limited access to the state of preservation of archival materials of winter sports, and thus objects related to sport, Tomasz Przerwa made the following statement: 'queries which were conducted in German facilities did not bring any positive results, a partial success was recorded only in the branches of the State Archives in Wroclaw [Przerwa 2012, p. 9].

A valuable source of information are press publications, namely pre-war tourist and sport periodicals as well as tourist folders, postcards and maps.

\section{Sports venues as green areas}

Sports terrains constitute an important link among greenery - 'pulsing with a characteristic calm rhythm of everyday life and great tensions of public holidays' [Wejchert 1955].

A characteristic feature of the first tourist facilities in the Giant Mountains was their location surrounded by greenery. Mountain shelters were usually situated in the most attractive corners of nature. When designing guesthouses, hotels and other tourist facilities, natural and scenic values of newly appropriated nature were taken into account. Buildings were constructed on large plots of land, often naturally undulating and away from roads. Landscape gardens were designed around buildings. Ideal were English park layouts, in which naturalness, coherence with the landscape as well as a romantic and sentimental atmosphere played the most important role in the arrangement. One of the natural layouts was the park near the house of Carl and Gerhart Hauptmann in Szklarska Poręba. Natural plant and rock formations, which were supplemented with imported tree and bush seedlings, were preserved here. Great attention was paid to the viewing axes towards the Giant Mountains massif. The shape of glades and free loose plantings gently complemented the annexed area.

Sports and recreational areas were also situated around the development, i.e. ski and toboggan and bobsleighs runs, ski jumping hills, ski lifts, tennis courts, swimming pools and ice rinks.

Most of these venues were of an outdoor character, contributing to a favourable balance of green spaces in the housing estate [Wintersport 1914]. They mostly used natural predispositions of the area, i.e. topography, water, vegetation, with only minimal interference in the environment. It was not exclusive to the Giant Mountains. In many famous mountain regions, the sports function was boldly introduced into the interiors of buildings, districts and housing estates using existing roads, squares, meadows, streams and ponds. An example can be Semmering resort in Austria, which is comparable to Szklarska Poręba and Karpacz. It was once called the Austrian St. Moritz, due to, among other things, the number of winter sports practiced there. The first toboggan runs were marked out along the streets. Sports venues were built near tourist facilities. They formed parks for sports and entertainment with large complexes of greenery. Thus, a bobsleigh track, a ski jumping hill, an ice rink, a ski lift and park areas were adjacent to Erzherzog Johan Hotel [Vasko-Juhasz 2016 p. 333]. At Panhans Hotel [Vasko-Juhasz 2016, p. 218] there were, among other things, toboggan runs and a swimming pool. Südbahnhotel [Vasko-Juhasz 2016, pp. 313-318] offered an experimental experience park, i.e. toboggan runs, tennis courts, children's playground, riding schools, cricket and golf grounds and space for gliding. Individual recreational areas were separated by a network of paths and roads. When composing layouts, the principles of the $18^{\text {th }}$-century landscape parks, which introduced freedom and romanticism, were in force. The naturally occurring rock and plant formations were cared for and juxtaposed with garden architecture. Nowadays, the 
complex does not exist in its original shape. There are traces of roads, little walls, groves, ponds and stone carvings. The mysterious atmosphere of the place, which used to turn into a winter sports paradise, also remained. Similarly, in Szklarska Poręba or Karpacz we can find fragments of structures and grooves in the ground of the existing in the past sports facilities. Resorts, in the early years of their tourist and sporting activities, functioned as almost the ideal of contemporary Alpine resorts. Sports zones penetrated deep into the town centre. People were skiing and sledging along mountain trails, forest vistas, but also down the streets and squares. Tourists used streams and rivers high in the mountains and inside the town in order to skate, play curling and hockey or to swim. Strategic points near sports routes were guesthouses, hotels and mountain shelters. Some of them even gained historical significance. Selected examples are presented below.

\section{Stops on sports trails}

Śnieżynka Hotel in Szklarska Poręba Fig. 1

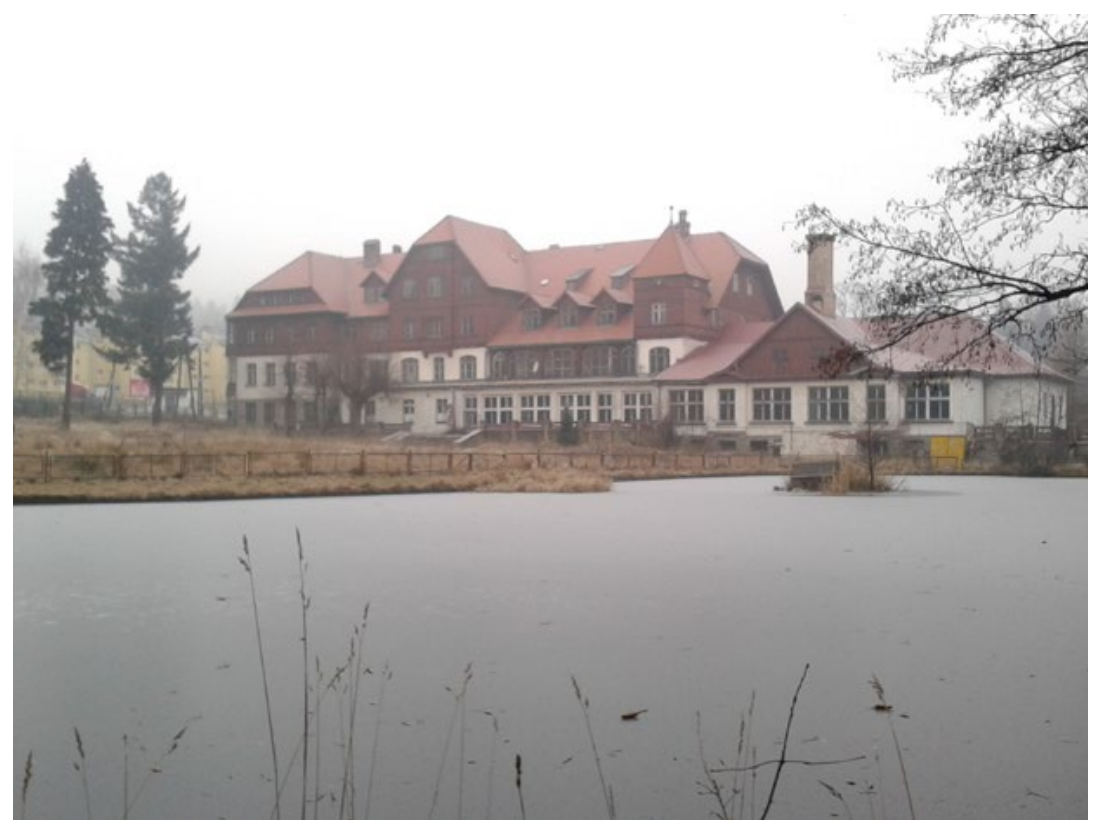

Fig. 1. Śnieżynka Hotel in Szklarska Poręba 2013 (photo by the author)

Śnieżynka Hotel, which was once called the Pearl of Szklarska Poręba, is a large building located on a large plot of land. The first postcards with the image of the building come from the late $19^{\text {th }}$ century. The facility performed the function of a hotel, guest house, sanatorium, high-class leisure centre. It was originally designed on the plan of combined rectangles. The two-storey central body with a two-storey attic dominated asymmetrically over the remaining one and two-storey structures. The southern façade overlooking peaks of the Giant Mountains opened onto the garden, pond, stream and sports grounds. A tripartite arrangement of verandas and dormers was flanked by twin towers. Horizontal cornice stripes of the particular storeys, window arched frames, boarded gables and parts of turrets above the eaves line, a wooden veranda structure contrasted with the brightly plastered façade. The geometric shapes of the compact gable roof were softened by pediments and dormers with decorative finials.

In the $20^{\text {th }}$ century, the building underwent modernization and was developed. From a 40-room hotel, it became a 60-room centre with extensive social spaces such as concert, conference and club halls as well as observation terraces. The central body's façade was almost twice as much widened by absorbing one of the side buildings. The whole was harmonized with the formwork of tops of the attic storeys. The storeys were gently suspended along with exposed ceiling beams. The change generally deprived the building of its original subtlety which was characteristic of architecture of Swiss hotels popular at that time. The new image strives to 
minimize detail while preserving traditional building forms, which makes the building blend in with the existing surroundings despite its large scale.

Initially, the centre offered mainly summer sports attractions such as tennis courts on the grass in the idyllic hotel garden. Bednarz stream swamp near the hotel was an additional advantage, which offered water recreation in summer and ice skating in winter. At the beginning of the $20^{\text {th }}$ century, the holiday house was advertised as a 'winter sports station'. This term was created due to the interesting neighbourhood of, among other things, a bobsleigh track which ended its course vis-a-vis the front of the southern façade ${ }^{1}$, surrounding ski and toboggan runs, including horned sleighs (including the toboggan run from the Pod Łabskim Szczytem Shelter and a ski route from Hala Szrenicka and Szrenica) [Schreiberhau 1915], ubiquitous gentle slopes - ski meadows. Nearby, on the bank of Kamieńczyk Stream, there was a ski jumping hill. As one of the few tourist facilities, the centre housed garages. It was a gesture of respect towards enthusiasts of trips, car and motorcycle races. According to pre-war folders, the facility was a station - the seat of an automobile club. The place was accurately chosen because in the 1930s Szklarska Poręba was considered to be the centre of car tourism in the Giant Mountains [Wohnungs 1929]. Friendly harmony between road and tourist trails was praised [Wohnungs 1939].

Once the place glorified for its idyllic atmosphere, clean air and views of the surrounding mountain ranges, now it has transformed into a rather busy area, i.e. a farm buildings square, a grouping of apartment blocks and a large supermarket store. Around the place where the bobsleigh track once ended, there is a summer toboggan run now. However, in the thickening of high greenery, in the mess of fences and service containers, the layout of the former rest house, which once harmonized with the neighbouring sports areas, is lost. There is also no trace of the golf course - the sport that was played in green areas south to the pond [Wohnungs 1939].

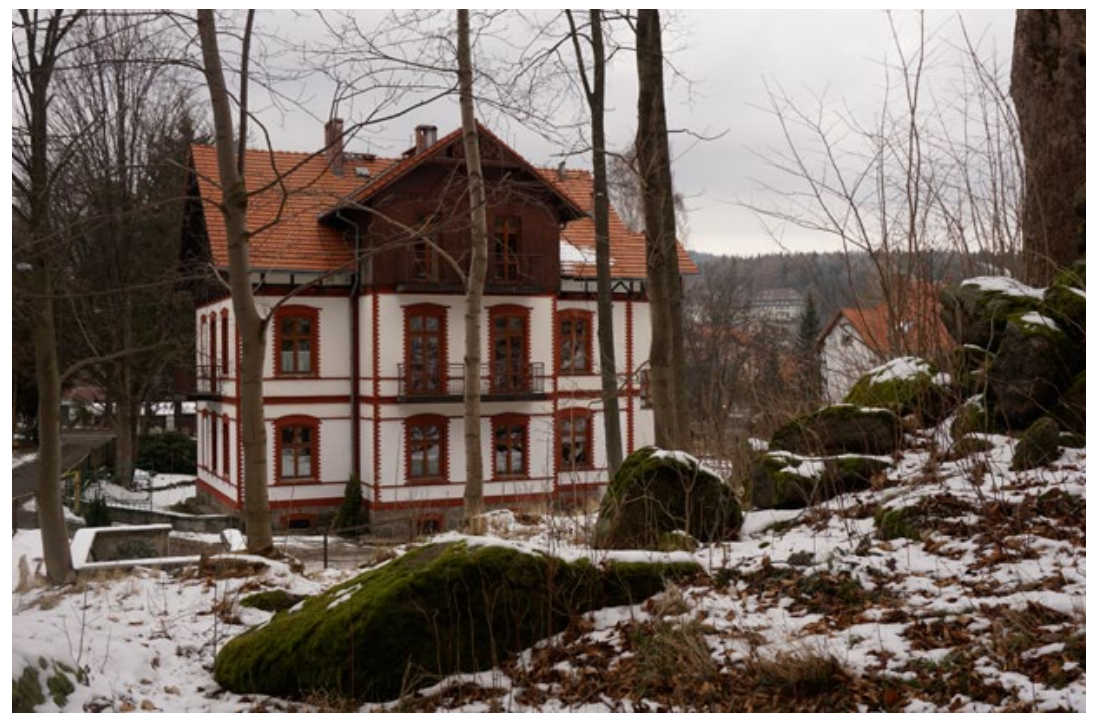

Fig. 2. Holiday House Słoneczko in Szklarska Poręba 2013 (photo by the author)

In the neighbourhood, however, a guesthouse has survived, the former Holiday House called Słoneczko Fig. 2 [Prospectus 1915], in a similar style to the original hotel building. It can be assumed that the hilly golf area, as well as the pond, picturesquely matched the guesthouse. At the beginning of the $20^{\text {th }}$ century, it had 16 rooms with verandas and balconies. It was a quite often duplicated type of a guesthouse from the late $19^{\text {th }}$ century. The rectangular body is broken by added three-storey avant-corpses (from the south with balconies and twin from the north with verandas). The whole is covered with a gable roof. The boarded attic zone, lace carving of the wooden structure of verandas and gables, horizontal divisions of cornices, window bands and wall cladding in the corners, and the indispensable stone pedestal diversify the simple body. It is now difficult to find relationships with recreational areas outside the property enclosed by the fence. 

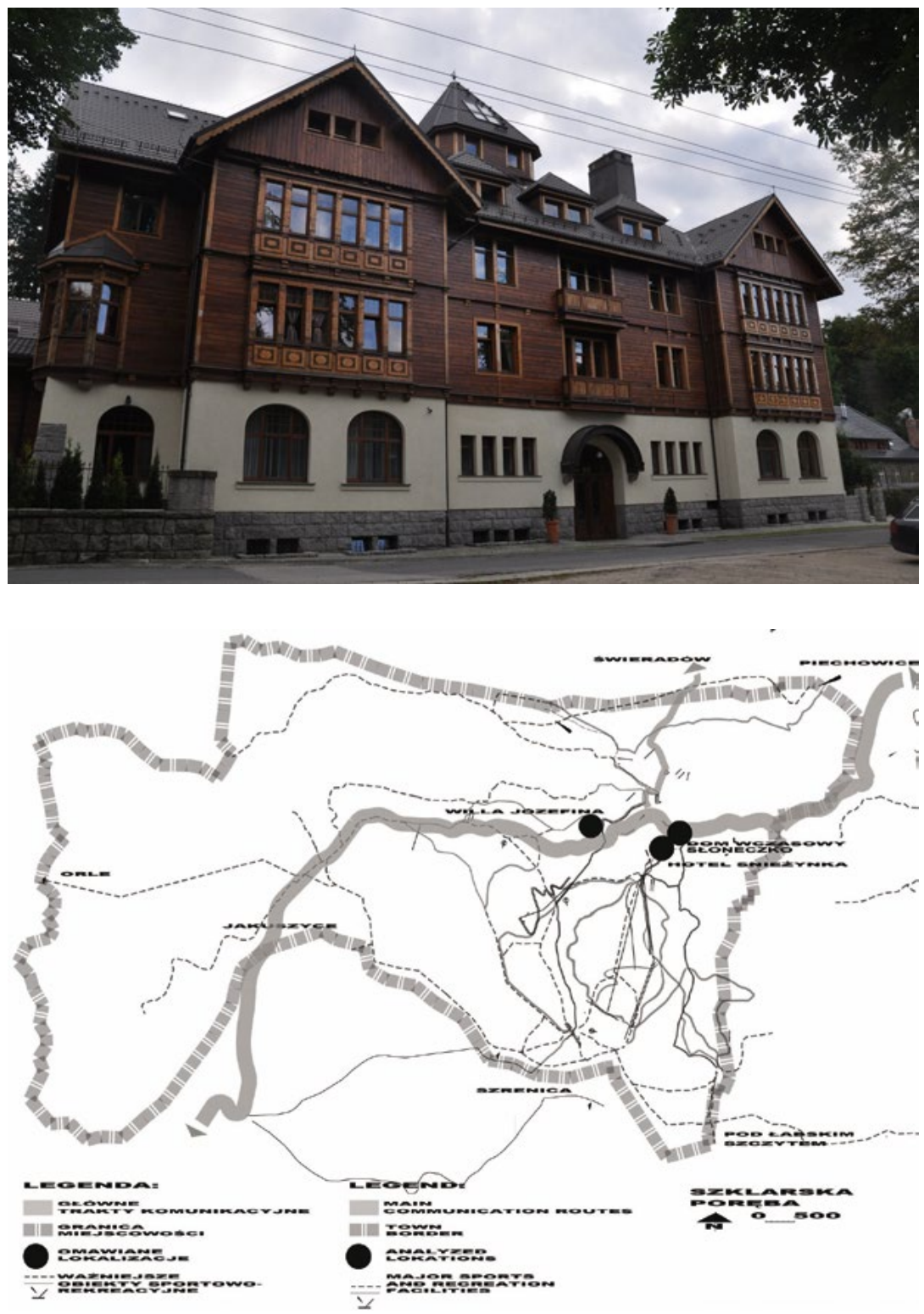

Fig. 3. Villa Józefina in Szklarska Poręba 2013 (photo by the author)
Fig. 4. Szklarska Poręba 2017 (illustration by the author)

In the place of the present Villa Józefina in Szklarska Poręba, a small one-storey inn with an attic was constructed at the end of the $19^{\text {th }}$ century. It was advertised as a haven for hikers, porters and mountain carriers. A typical rectangular building with a centrally located two-storey porch, in a rim construction with prominent quoins, was covered by a gable roof with substantial eaves.

In the $20^{\text {th }}$ century, the building was extended by adding an elongated one-storey gastronomic pavilion and then in 1911 magnificent three-storey cubature with an attic in the place of the inn was constructed. The main building was founded on a rectangular projection divided by avant-cropses. The lower annexes adjoined the building and were hidden behind the front façade. The brightly plastered ground floor contrasted with the horizontal formwork of the first and second storeys and the vertical formwork of the gables. The particular storeys were separated by a frieze with a rhythmic arrangement of protruding ceiling beams. The ground floor windows were crowned with arches and on the upper floors rectangular window openings were characterized by a small division of quarters. Against the background of hardly perceptible ornamentation, a corner 
bay window on a polygonal projection stood out - like a tower in the front façade. The mountain hotel offered 40 rooms, game rooms, a reading room, a large garden, terraces, etc. The object was famous for its station of horned sleighs. It was also recommended as an ideal place for all types of winter sports. It was located on the tourist trail which led to Kamieńczyk Waterfall and then to Hala Szrenicka, the Giant Mountain Ridge along the road to Jakuszyce. Here, there were also sleigh runs (horned sleigh as well), including a two-track, collision-free and the most favourite route, namely Hala Szrenicka - surroundings of Kamieńczyk Waterfall - Szklarska Poręba. From here it was not far to the sports complex at Kamieńczyk Waterfall, which consisted of ski jumping hills, a bobsleigh track, a shooting range, cross-country ski runs and downhill runs, lifts. The investments made and development plans were connected with favourable snow conditions in this region. The track of popular car and motorcycle races was also situated nearby [Wiater 2017]. The hotel had thirteen garages and a petrol station which both met expectations of motor sports enthusiasts.

The building underwent thorough remodelling, maintaining its historic image. However, the hotel, which was deprived of an attractive neighbourhood of sports grounds, became a roadside apartment building. None of the sports facilities mentioned here exists anymore and they have not been replaced by other modern ones.

Orlinek Hotel in Karpacz Fig. 5 [Suchodolski 2014, pp.128-129]

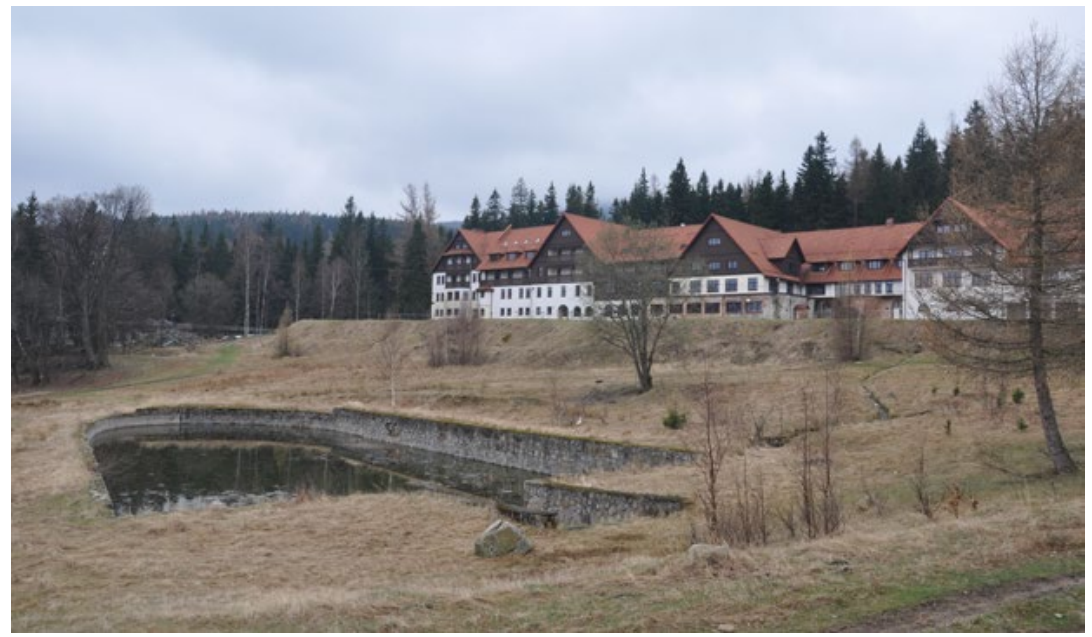

Fig. 5. Orlinek Hotel in Karpacz 2016 (photo by the author)

In 1913, on an extensive mountainous glade in the vicinity of Karpacz, a mountain hotel was constructed. It was a two-storey building with a two and three-storey facility attic. The elongated body, asymmetrically divided by transverse structures of varying heights, was connected with Buda Pod Wąsem mountain shelter which existed probably since the $18^{\text {th }}$ century (in 1923 the shelter burned down) by means of a long, low, one-storey shed. This connector, which was incorporated into the slope, constituted a sports and recreation building - a bowling club with a visible timber framing structure of walls and gable roof beams. Later, it was enclosed with multi-pane windows and wooden panels with woodcarving. The hotel building, with 200 beds, duplicated a traditional repertoire of forms, adapting to the historical development, despite a disproportionate scale, i.e. a steep gable roof, dark brown formwork of the attic and dormer storeys, loggias, verandas, white plaster of lower storeys, arched window openings and door basements. An unconventional, but often used solution was a polygonal corner bay window in the exposed front façade and a decorative motif made of stylized leaves, covering the entrance opening along with equally decorated gates. However, rich wall ornaments were found in the interiors of the building, namely in dining rooms, restaurants and cafes.

The building elegantly dominated in the extensive forest glade, at the same time standing out against the background of the monstrous range of the northern slopes of the Giant Mountains. Tourist and sport routes, which descended from the highest parts of the mountains, crossed in this place. Tracks which spirally ran to the centre of Karpacz started here. A large tourist and sports complex was created along with facilities and tracks such as a ski jumping hill, a bobsleigh track, ski runs (from the mountain shelter Nad Małą Łomniczką, from the mountain shelter Pod Śnieżką and from the mountain shelter Strzecha Akademicka), toboggan runs (one trail 
that was long - Silesian Road and a network of other and shorter ones which led to Karpacz), tennis courts, a small water reservoir which was used extensively in winter and summer. In winter, the sloping meadow in front of the hotel turned into a great ski and sledge slope. Ski courses, ski and toboggan competitions were organized there. In the summer season, tennis tournaments which were modelled on famous resorts, were organized.
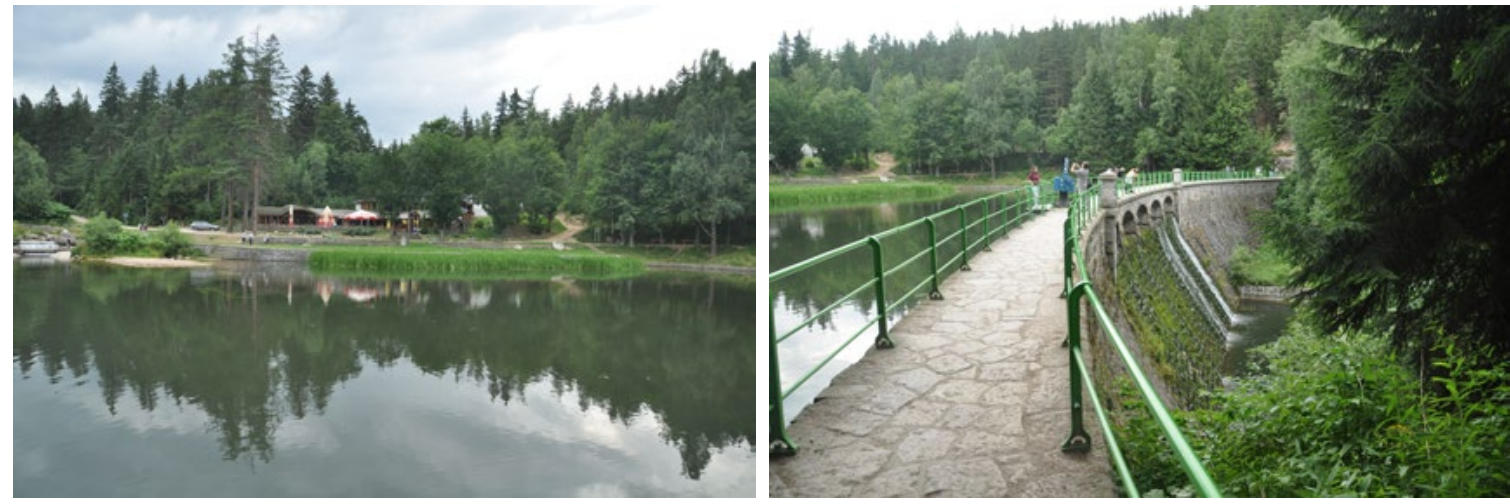

Fig. 6. Restaurant by Łomnica reservoir in Karpacz 2015 (photo by the author)

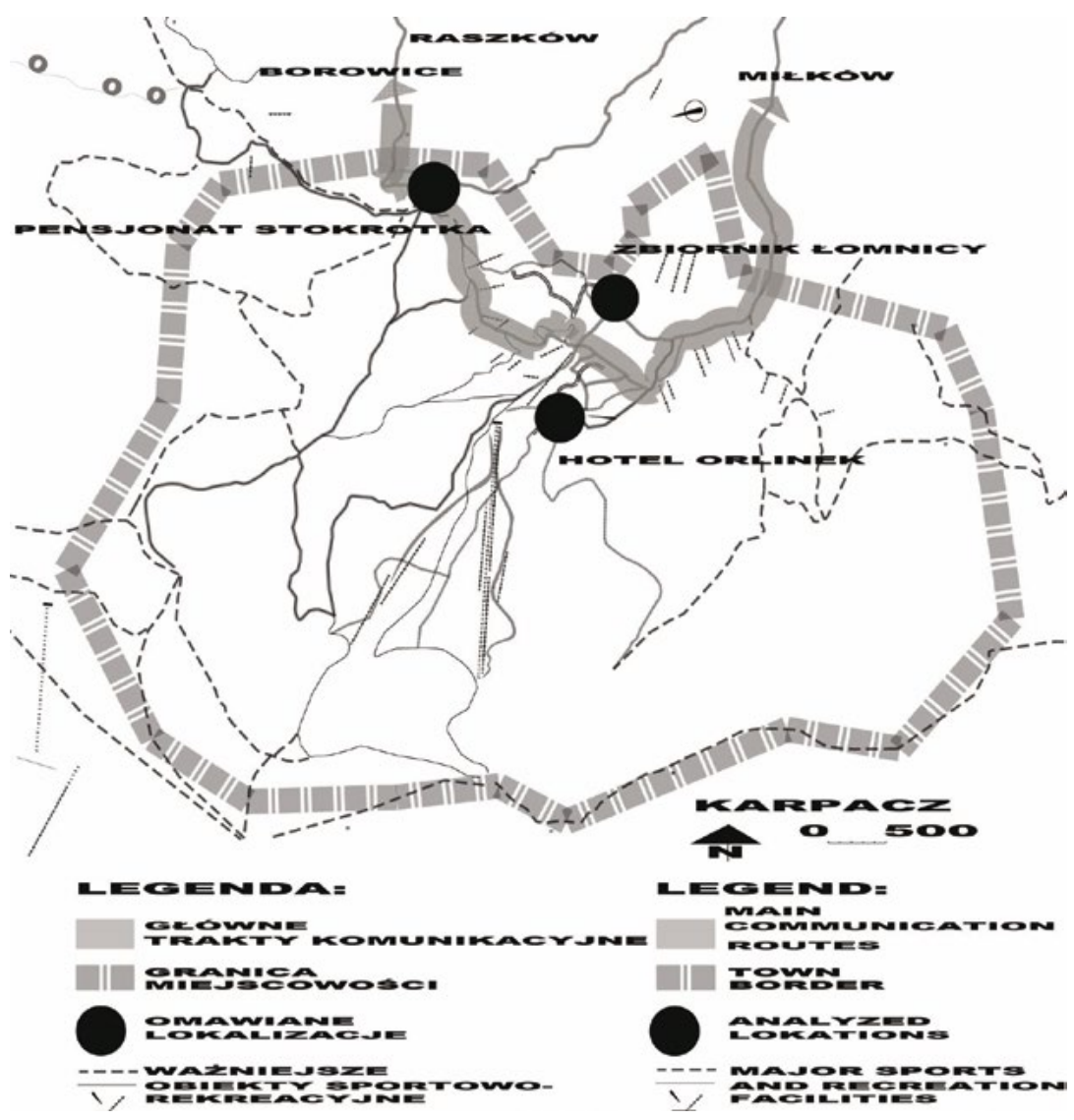

Fig. 7. Karpacz 2017 (illustration by the author)

The hotel, which was rebuilt many times, is now closed and the ski jumping hill, which was replaced with a new one, i.e. Stanisław Marusarz, has not been functioning since 2010. The bobsleigh track left recesses in the ground in some places. However, the sports grounds above the hotel, in the vicinity of Strzecha Akademicka mountain shelter and Kopa, have survived in a changed form. In 1960 a chairlift to Kopa was opened here for 
tourist and sport traffic. It was the first rope lift in the country and the longest chairlift in the world at that time. It was $2278 \mathrm{~m}$ long and covered a land difference of $528 \mathrm{~m}$. At present, it is the oldest lift in Poland. Over the following years, the sport infrastructure was supplemented by constructing six cable lifts and one gondola lift. In 2011, the youngest Biały Jar Station was established. It was realized, as if against the trend that locates ski investments high in the mountains. It was even successful to place the lower station close to the centre of Karpacz. The only cross-country trail from the upper cableway station to Kopa is advertised, towards Dom Śląski and Lucna Bouda mountain shelters.

Stokrotka Guesthouse, which is also worth mentioning, [4, p. 131] was added to Buda Chlebowa Shelter on the pass near Czoło above Karpacz in 1895. It was always a strategic and scenic location, which was crossed by numerous ski and toboggan routes, i.e. the route from Karpacz to the then Borowice (and further to Przesieka and Czerwoniak, Raszków and Miłków), the ski run next to Husycka Górka towards Łomnica reservoir, the toboggan track along Karkonoska Street to the centre of Karpacz and further to Miłków and the other leading to Miłków along the forest path and the slope of Strzelec Mountain. The trails from Wielki Staw area from the shelter of Prince Henry, the shelter of Bronek Czech, the shelter of Strzecha Akademicka and other parts of Równia pod Śnieżką converged or looped here. At present, only the 2,500 cross-country skiing loop near the guest house is used in winter.

One of the most interesting places near sports tracks is a restaurant Fig. 6 [Suchodolski 2014, p. 133] with several beds on the banks of Łomnica reservoir in Karpacz - once a mountain shelter from 1915 il. 5. A one-storey wooden structure building with an attic crowned with a gable roof and a large open veranda (later glazed), with a small scale gently blended into the natural environment of the wild and winding River Łomnica in this place. Sport life was vibrant on the dam lake in Łomnica. In winter, hockey, curling, ice skating were practiced on the ice rink, whereas in summer a harbour for boats and kayaks was organized. Nearby, just behind the restaurant, there was the finish of the bobsleigh track. There was a cross-country ski trail here and the sledge run curved here. Nowadays, these sports are not practiced. A much larger gastronomic facility was constructed in the place of the historic building.

\section{Summary}

Analysing the form and location of tourist facilities such as guesthouses and hotels in the Giant Mountains at the turn of the $20^{\text {th }}$ century, it should be concluded that many of them made up comprehensive layouts. They consisted of characteristic architecture, integrating landscape, a large reserve of green areas, including sports ones. Buildings had features of native architecture with features of Swiss hotel architecture. They were integrated with elements of the landscape in which mountains were of special significance. Multifunctional centres offered a high quality of created space without settlement boundaries, remaining in balance with the surroundings, unscathed for such desirable tourist attractiveness. Thus, these places were permanently remembered because of their beauty and pleasure of practising sports or recreation.

On the basis of the Karpacz spatial development (zoning) plan from 1922, it can be concluded that the location of sports and green areas was anticipated by taking into account aesthetic aspects as well. Sports tracks penetrated smoothly into the designed layout of construction plots separation in accordance with the location of contour lines. Larger structures were not located accidentally because they emphasized selected sites or characteristic forms of landform. Scarps were marked, even the smallest ones on private properties! Newly designed plots duplicated large areas of the existing construction plots. The distance between developments was kept.

At present, the surroundings of Śnieżynka Hotel and Słoneczko Guesthouse have been occupied by residential and commercial development. Postcards from the $20^{\text {th }}$ century which depict the above-mentioned buildings with active vacationers are intriguing. Orlinek, Stokrotka and Villa Józefina lost their statute for strategic hotels and sports and tourist guesthouses along with the liquidation of sports tracks and venues. Disturbingly empty spaces in their surroundings can become attractive for developers.

It is worth quoting the reflection of architect Laurent Chappis, who was one of the first to settle the French Alps for the needs of a flourishing tourism and sports movement. 'It is important that those who come to the mountains see the mountains first, not architecture and urban planning overlooking the mountains. We must be very humble'. 


\section{Literature}

[1] Biesiekierski T., Suchodolski J., Trocka-Leszczyńska E., 1999: Architektura na obszarze Sudetów: Sudety Środkowe, Wschodnie i Przedgórze Sudeckie, Oficyna Wydawnicza Politechniki Wrocławskiej, Wrocław.

[2] Balińska G., 1991: Uzdrowiska dolnośląskie: problemy rozwoju i ochrony wartości kulturowych do II wojny światowej, Wydawnictwo Politechniki Wrocławskiej, Wrocław.

[3] Diener R., Herzog J., Meili M., de Meuron P. Schmid Ch., 2005: Switzerland - an Urban Portrait, [b.m.], 212.

[4] Janczak J., 1976-1985: Rozwój uzdrowisk i turystyki w: Historia Śląska, t. 3 pod redakcją Stanisława Michalkiewicza, cz. 1-2, Ossolineum Wrocław.

[5] Janczak J., 1988 "Z kuferkiem i chlebakiem: Z przeszłości uzdrowisk i turystyki śląskiej", Wydawnictwo PTTK Kraj Warszawa - Kraków.

[6] Koeppen A., 1908/09: Die Schreiberhauer Künstlerkolonie, "Schlesien", Nr 2, 465-471.

[7] Koeppen A., 1909/10: Zur Wiederbelebung schlesischer Bauernhäuser, "Schlesien", Nr 3, 559-562.

[8] Łaborewicz I, Wiater P., 2010: Szklarska Poręba: Monografia historyczna, AdRem Jelenia Góra.

[9] Mazurski K., 2012: Historia turystyki sudeckiej, COTG PTTK Kraków.

[10] Potocki J., 2004: Rozwój zagospodarowania turystycznego Sudetów od połowy XIX wieku do II wojny światowej, Jelenia Góra.

[11] Potocki J., 2009: Funkcje turystyki w kształtowaniu transgenicznego regionu górskiego Sudetów, WTN Wrocław.

[12] Przerwa T., 2012: Między lękiem a zachwytem. Sporty zimowe w Śląskich Sudetach i ich znaczenie dla regionu (do 1945). Oficyna Wydawnicza ATUT Wrocław, 9.

[13] Prospekt von Schreiberhau im Riesengebirge mit Wohnungs - Verzeichnis, 1915: Herausgegeben vom Verkehrs-Ausschuss der Gemeinde Schreiberhau Schreiberhau.

[14] Reichs Handbuch der Deutschen Fremdenverkehrsorte. 1938: Verlag Erwin Jäger, Berlin, 556.

[15] Schreiberhau im Riesengebirge Klimatischer Höhenluftkurort Wintersportplatz, Sommer 1929: Hrsg. von der Kurverwaltung Schreiberhau Schreiberhau.

[16] Schreiberhau im Winter, 1915: Hrsg. Vom Verkehrs - Ausschuss der Gemeinde Schreiberhau, 22.

[17] Steć T, Walczak W., 1962: Karkonosze: monografia krajoznawcza, Wydawnictwo SPORT I TURYSTYKA Warszawa.

[18] Suchodolski J., 2014: Architektura schronisk górskich w Sudetach, Oficyna Wydawnicza Politechniki Wrocławskiej, Wrocław.

[19] Suchodolski J., 1996: Regionalizm w kształtowaniu formy architektury współczesnej na obszarze Sudetów, Oficyna Wydawnicza Politechniki Wrocławskiej, Wrocław.

[20] Szymanski-Störtkuhl B., Ilkosz J., 1999: Od zagrody do willi. Architektura Kolonii Artystycznej w Karkonoszach, [w:] K. Bździach (red.), Wspaniały krajobraz. Artyści i kolonie artystyczne w Karkonoszach w XX wieku, Gesellachaft für interregionalen Kulturaustausch e.V., Berlin Muzeum Okręgowe w Jeleniej Górze, Berlin i Jelenia Góra.

[21] Trocka-Leszczyńska E., 1995: Wiejska zabudowa mieszkaniowa w regionie Sudeckim, Oficyna Wydawnicza Politechniki Wrocławskiej, Wrocław.

[22] Urządzenia sportowe Projektowanie i budowa red Romuald Wirszyłło, 1966: Wydawnictwo Arkady Warszawa, 7.

[23] Vasko-Juhász D., 2006: Die Südbahn Ihre Kurorte und Hotels, Böhlau Verlag, Wien Köln Weimar.

[24] Wejchert K., 1955: Znaczenie terenów sportowych w osiedlach, red. Instytut Urbanistyki i Architektury, Tereny i urządzenia sportowe, Wydawnictwo Budownictwo i Architektura Warszawa, 7.

[25] Wiater P., Zimowa infrastruktura Szklarskiej Poręby do 1945 roku [online]. [dostęp 30.06.2017]. Dostępny w Internecie:http:// www.szklarskaporeba.pl/files/ciekawostki\%20historyczne/Zimowa\%20infrastruktura\%20Szklarskiej\%20poreby\%20 do\%201945\%20r.pdf.

[26] Wintersport und Winterreisen im Riesengebirge Praktischer Reisefuhrer, 1914: [b.m].

[27] Wohnungs verzeichnis. Heilklimatischer Kurort und Wintersportplatz, 1929: Herausgegeben von der Kurverwaltung Schreiberhau, Schreiberhau.

[28] Wohnungs Verzeichnis. Heilklimatischer Kurort und Wintersportplatz Schreiberhau im Riesengebirge 1939: Hrsg. von der Ortsstelle Schreiberhau der Wirtschafts - gruppe Gaststten und beherbergungsgewerbe in Zusammenarbebit mit der Kurverwaltung Schreiberhau, Hirschberg.

[29] Wróblewski S., 2016: Zieleń zespołów sportowych z okresu dwudziestolecia międzywojennego na Dolnym Śląsku Teka Komisji Architektury, Urbanistyki i Studiów Krajobrazowych XII Nr 4, PWN Lublin, 107-123. 